\title{
Helyrajz
}

\section{Szabolcs-Szatmár-Bereg megye településeinek rehabilitációja}

\section{Topography The rehabilitation of the Szabolcs-Szatmár- Bereg county's settlements}

\author{
G. LÁDI \\ University of Debrecen, ladigabriella@freemail.hu
}

Absztrakt. A dolgozat célja, hogy feltárja a Szabolcs-Szatmár-Bereg megyei falvak problémáit, és ezekre megoldási javaslatot adjon. A kis léptékü települések megörzése fontos lenne, hiszen kultúránk múltját őrzik. Az itt élők is igényt tartanak a városi létre, így célszerü lenne a falvakat ennek irányába mozdítani. A ldo van Eyck munkásságára alapozva a játszóterek - melyek városi környezetben élnek - falusi léptékét kerestem. Az ehhez elkészített morfológiai csoportosítás jól mutatja a települések eredeti képét. Ezekbe a telepítésekbe a játszóteret beillesztve, elmozdulás történhetne a város irányába, és felhívhatná a figyelmet ezeknek a településeknek a fontosságára.

Abstract.The purpose of the dissertation to explore the problems of the Szabolcs-Szatmár-Bereg county's villages and to give solving advices for these problems. The conservation of the small-scaled settlements is important because these are our culture's past. The villagers are claiming for the citylife, so it will be excedient to form the villages in this way. I took Aldo van Eyck's life-work as a basis and I looked for the playground's village-sized scale. The morphologic grouping what was made for this searching has a good effect of the settlements's original texture. If the playgrounds be fit in the settlements's structure there will be a changing and draw the attention to the significance of these settlements.

\section{Bevezetés}

A települések és lakosságának helyzete utáni érdeklődésem következtében készült dolgozat feltárja a falvakban kialakult problémákat. A megoldás keresése során a településeket morfológiailag csoportosítottam. Az így kialakult típusokra egy-egy településen bemutatott rehabilitációs példát készítettem. A példákat Aldo van Eyck építészetére alapozva igyekeztem elkészíteni, ami az amszterdami játszótereiben öltött formát először, és forrott ki. Ezek a terek a városi környezetbe illeszkedtek, szakítottak a múlttal. Kialakításukkal segítették a gyerekek számára a fejlődést játékos formában. Ez alapján a játszóterek rendelkeznek olyan erővel, ami amellett, hogy telepítésével őrizné a falu múltját, javítaná az itt lakók közérzetét. A közterület alakításával elmozdulást jelenthetne a város felé, picit a fejlődés irányába terelné ezeket a településeket, hiszen a falusiaknak is megvan az igénye a városi létre, csak a későbbiekben ismertetet problémák miatt nincs lehetőség ennek az igénynek a kielégítésére. Ezért is kerestem a játszótereknek a falusi léptékét. 


\section{Miért van erre szükség?}

Szabolcs-Szatmár-Bereg megye az ország észak-keleti részében a Nagyalföld részeként helyezkedik el. 229 települése 5933 km²-n terül el, melyből Nyíregyháza megyei jogú város, további 27 település városi rangot kapott. Lakossága 2015. január elsejei adatok szerint 562357 fő volt. [1]

\subsection{Földrajz}

A megyét a Nyírség több mint 70\%-a, a Rétköz és a Szatmár-Beregi síkság képezi. Egyhangú területek, melyek mai formájukat az eltűnt folyóknak, patakoknak, lápoknak, mocsaraknak köszönhetik. A települések morfológiai alakulásában ez az eltűnt gazdag vízhálózat, illetve az egyház játszott nagy szerepet. [2]

\subsection{Lakosság}

A települések fejlődését a falusiak változásokhoz történő hozzáállása is nagyban befolyásolta. Karácsony Sándor A magyar észjárás című művét elemezve próbáltam a falusiak gondolkodását leírni, illetve saját tapasztalatok alapján a mai helyzetet felvázolni.

Karácsony sándor az iskolai reformokat boncolgatva megállapítja:

- a nép alulra került rétege a XVII. századi formáját őrzi

- a falu és az alsó néposztály helyzete szorosan összefügg, hiszen az alsóbb néposztályok a falvakba szorultak

- nem látják a lehetőséget a fejlődésre, megmaradnak a saját kis világukban

- szűklátókörűek

A falvak és a városok közötti társadalomban látható nagy szakadékot az alsó néposztály taníttatásával lehetne megszüntetni, és kellene, hiszen az ő kultúrájukból táplálkozik a középosztály és a szofokrácia rétege.

A falusiak taníttatása viszont nehézkes, mivel a városiakkal ellentétben ők gyakorlatiasan logikusabban gondolkoznak, amit nem tapasztalnak, és nem látnak azt nehezebben, vagy egyáltalán nem is értik meg. Nem nyitottak a város felé. [3]

A rohamos fejlődésnek köszönhetően azonban ez a társadalmi szakadék eltűnt, kialakult egy közvetlenebb kapcsolat város és falu között. A tanult falusiaknak nincs lehetősége az elhelyezkedésre ezeken a kis léptékű településeken. Megjelenik ez által az igény a falusi emberben a városi életre, a jobb megélhetés érdekében. Új probléma: a falvak elnéptelenedése. 


\subsection{A történelme}

A szegénység elnéptelenedés azonban nem új jelenség a megyében. Évszázadokra visszamenőleg megfigyelhető, és visszatérő probléma.1650-es évek, török hódoltság időszaka szegénységbe sodorta a területet, csak a XVII. századtól kezdődött meg a fejlődés, egészen az 1831-es kolerajárványig. Ezután a napóleoni háborúk gazdasági felpezsdülést hoztak, birtokosok körében kastélyok kúriák építése vette kezdetét parkos erdős részekkel kialakítva, ezek viszont pusztították a természetet. Az orosz invázió utána a földújraosztás, a művelendő területek védelme és ezért a Tisza szabályozása segített a szegénységen. 1876-ban új megyeszékhely jön létre Nyíregyházán, megkezdődik a megyében az út és vasúthálózat kiépítése. Az árpád kór óta minimálisan változó felosztása a megyének ezzel megszűnt. A változás teljesen átalakította a tájat. A mezőgazdaság a 19. század végére zuhant válságba, kivándorlás vette kezdetét. [2] 1914-45 közötti időszak mély válságba sodorta a területet, a trianoni békeszerződéssel, elcsatolták az út és vasúthálózat nagy részét, további elvándorlás jött létre. 1950ben Szabolcs-Szatmár néven egyesül a megye. A fellendülést a 2008-as világválság szakította félbe. [4]

\section{Rehabilitációs lehetőségek}

Ezeknél a falvaknál viszont véleményem szerint nem csak a munkalehetőségek teremtése, és ezzel az emberek itt tartása lenne a cél, hanem a közösség összefogása is fontos.

A falusiakat érő negatív hatások mellett, a folyamatos fejlődés, ahogy már korábban is említettem, igényt tart a városi lét falun való megjelenésére.

Aldo van Eyck építészete játszótereiben érett meg. Ezeknek a tereknek a legnagyobb részét a város, különböző pontjain helyezte el. [5]

Ma már azonban egyre gyakrabban előfordul a vidéki településeken való megjelenése is a játszótereknek.

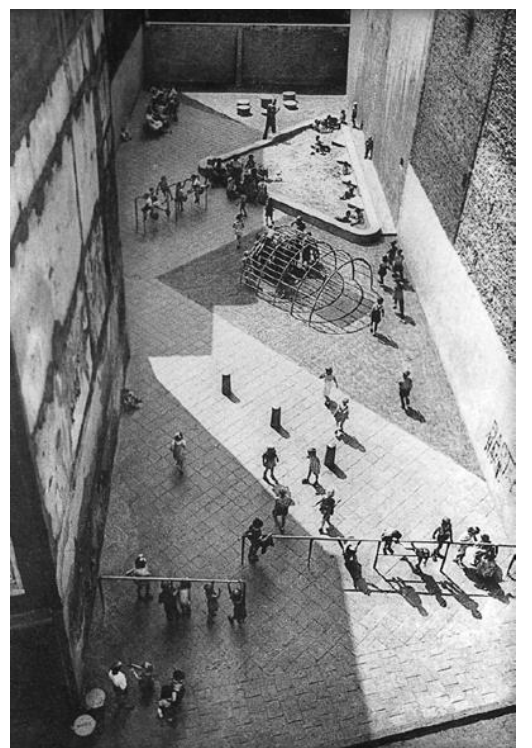

1. ábra: Aldo van Eyck Playground, Amszterdam, Dijkstraat [7] 


\section{Morfológiai csoportosítás}

Ezt véve alapul kerestem a módját, hogyan lehetne a falu képébe illeszteni ezt e teret.

A vizsgált településeknél megfigyelhető, hogy nincs rendezett, közösséget vonzó központ kialakítva. Ez viszont különösen fontos lenne, hiszen a városoknál és nagyobb léptékű településeknél is jól megfigyelhető ennek a kiemelt szerepe. Így egyértelműnek tűnt számomra, hogy a játszótereket úgy telepítsem, hogy a közterületet alakítsa, és ne a mindenhol látható termékekként jelenjenek meg. A települések morfológiai csoportosítása ehhez elengedhetetlennek bizonyult.

229 település közül 35, 3000 fő feletti

\section{2, 3000 és4000 közötti}

100 település pedig ezer fő alatti [1]

Térképeket és települési sajátosságokat vizsgálva 4 csoportot sikerült kialakítani.

\subsection{Mag, víz, tölcsér és zsákutca típusú településeket.}

Mind 4 típusról elmondható, hogy az úthálózat vagy egy földrajzi adottsághoz, vagy az egyházhoz igazodott. Erre az úthálózatra merőleges irányba szerveződtek a telkek. A telkek beépítése pedig a falura jellemzően oldalhatárra történt, a hátsó melléképületeket pedig egymás mögé a telek hosszirányába építették tovább, akár különállóként, akár toldásként. Az épületek melletti keskeny udvart megőrizték. Az útszakaszok által közrezárt terület beépítettsége típusonként, sőt településenként változó.

\subsubsection{Mag típusú települések}

Már a katonai térképeken is jól látható, hogy a templom a mag, emellett fut a főút, és egy mellékággal kikerülve körülöleli a területet. A játszótér elhelyezése során az általános jellemzők mellett a mag alakú tér sajátosságait is igyekeztem figyelembe venni. A tér templommal átellenes pontján a, annak mintegy párjaként a tengelyre szervezve helyezkedik el a játszótér. A játékok elhelyezésével a telkek beépítettségét igyekeztem visszaidézni.

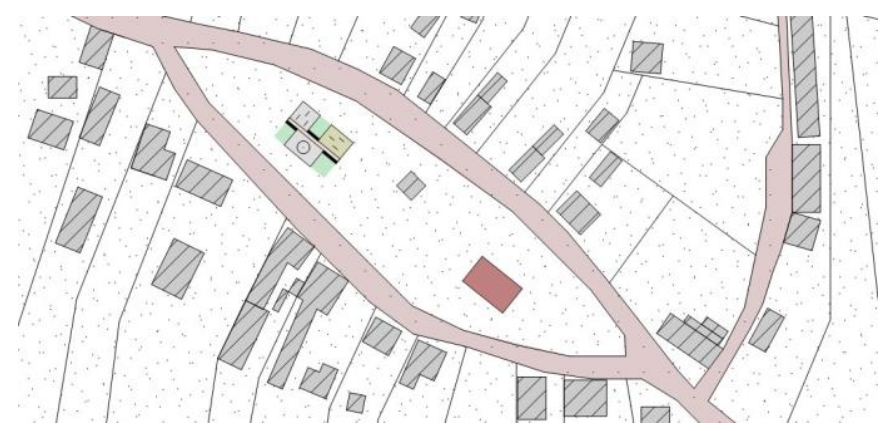

2. ábra: Garbolc települése (saját szerkesztés) 


\subsubsection{Víz típusú települések}

A folyókra, patakokra szerveződő települések esetén a gazdag növényzet jól mutatja az egykori vízfolyások helyét. Ez a terület mai napig beépítetlen marad.A település képére mintázva a játékok mintha egy folyópart két oldalán lennének elhelyezve.

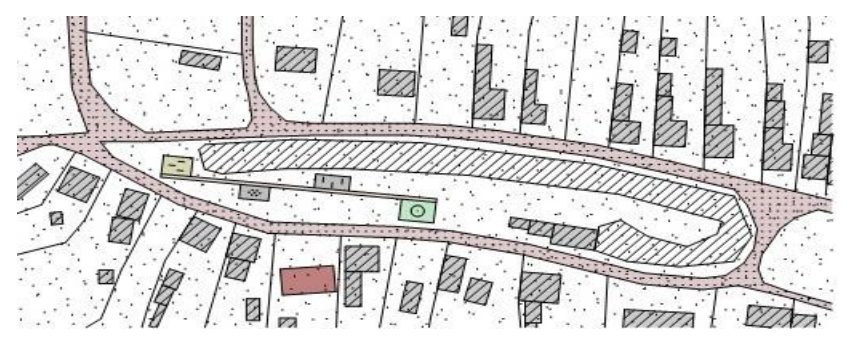

3. ábra: Darnó települése (saját szerkesztés)

\subsubsection{Tölcsér típusú települések}

Ezek a falvak összefutó utak találkozására települtek. A mag típusú településekkel ellentétben ezek az utak a templomra vezettek rá, és nem kikerülték őket. A két útszakasz tölcsérszerűen futja körbe a templomot, továbbá egyes estekben egy a mindkét útszakaszra merőleges utca lezárja ezt a térrészt. Ezeknél a falvaknál nem mindig maradt meg tisztán a tölcsér, mivel gyakran nagy a kiterjedése beépített területek alakultak ki.A játszóteret szintén az eredeti településképet őrző térrészre helyeztem. A játékok közötti sávoknál a telek elrendezését igyekeztem visszaidézni, ferdeségükkel azt a szigorú rendet megtörve, ami a településen látható.

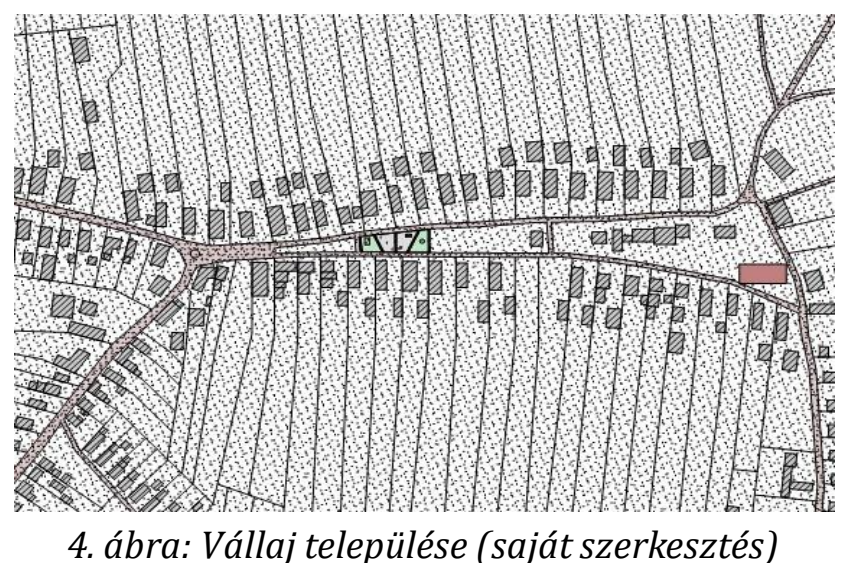

\subsubsection{Zsákutca}

Lápos mocsaras területre szigetként ékelődő települések. Az utca befutott erre a szigetre, megkerülte a templomot, így csak egyetlen ponton lehetett a településre bejutni és onnan ki. A katonai felméréseken is szerepel már olyan település ami megnyílt mind a két irányba, mára viszont ezek mindegyikéről elmondható. A játszótér elemeit is úszó szigetekként helyezném el a templom területén. 


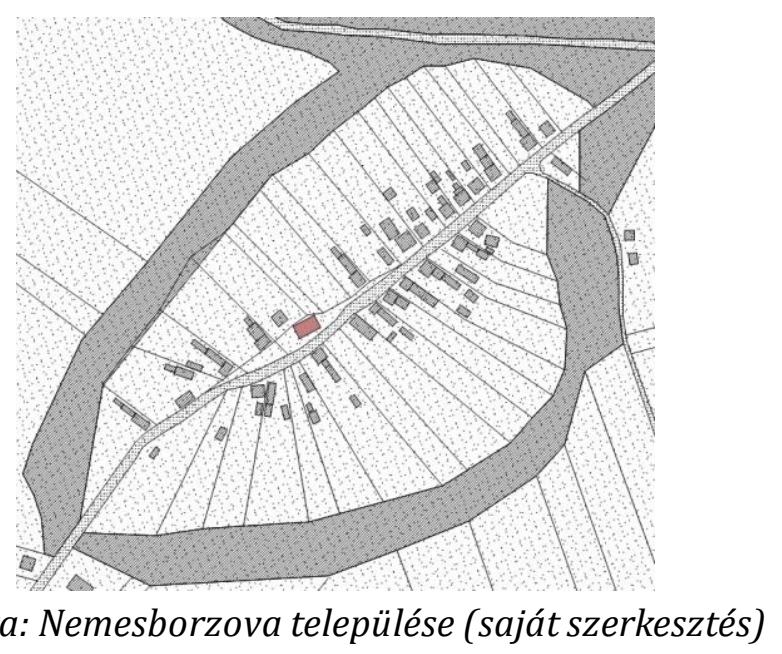

A játszóterek elhelyezése a faluban kezdeti megoldásként szolgálhatna, hogy felhívjuk a figyelmet az itt lévő problémákra, kicsit a települések irányába fordítva a tekintetet. Az értékek hagyományok szokások, amik ezekben a falvakban megbújnak, egyre kevesebb területen találhatóak meg. Őrizni kellene őket vigyázni rájuk, akár csak egy gyermekre.

\section{Hivatkozások}

[1.] Központi Statisztikai Hivatal: Magyarország közigazgatási helynévkönyve 2015. január 01., Budapest, Központi Statisztikai Hivatal, 2015 ISSN: 1217-2952

[2.] Kasza Sándor: Szabolcs-Szatmár-Bereg megye kézikönyve 15. kiadás, 1998 CEBA kiadó, Budapest, 1010 p. Magyarország megyei kézikönyvei. ISBN: $96390890010 ̈$

[3.] Karácsony Sándor: A magyar észjárás 2. kiadás, 1985 Magvető Könyvkiadó, Budapest, 562 p., Magyar Hírmondó, ISBN: 9631403610

[4.] http:/www.szabolcsmegye.com/szabolcs-szatmar-bereg-megye/a-gazdasagi-valsag-szabolcsmegyet-sujtotta-a-legjobban

[5.] Kerékgyártó Béla: A mérhető és a mérhetetlen - Építészeti írások a huszadik századból, 2. kiadás, Budapest: Typotex Kiadó, 2004., 430 p. ISBN 9639548448

[6.] https://merijnoudenampsen.org/2013/03/27/aldo-van-eyck-and-the-city-as-playground/

[7.] http://artbooks.yupnet.org/2015/01/16/sneak-peek-aldo-van-eyck/

[8.] Pogány Frigyes: Terek és utcák művészet, 2. kiadás, Budapest, Műszaki Könyvkiadó, $1960,448 \mathrm{p}$.

[9.] Meggyesi Tamás: Települési kultúráink, 1. kiadás, TERC, 2008,70 p. ISBN: 978963 9535725 